\title{
Efficacy of local budesonide therapy in the management of persistent hyposmia in COVID-19 patients without signs of severity: A structured summary of a study protocol for a randomised controlled trial
}

Mary Daval ${ }^{1 *}$ D, Alain Corré ${ }^{1}$, Clement Palpacuer ${ }^{1}$, Juliette Housset ${ }^{2}$, Guillaume Poillon $^{1}$, Michael Eliezer $^{2}$, Benjamin Verillaud ${ }^{2}$, Dorsaf Slama ${ }^{3}$, Denis Ayache ${ }^{1}$, Philippe Herman², Clement Jourdaine ${ }^{2}$, Camille Hervé', Wissame El Bakkouri ${ }^{1}$, Dominique Salmon ${ }^{1}$ and Charlotte Hautefort ${ }^{2}$

\footnotetext{
Abstract

Objectives: To assess the efficacy of local intranasal treatment with budesonide (nasal irrigation), in addition to olfactory rehabilitation, in the management of loss of smell in COVID-19 patients without signs of severity and with persistent hyposmia 30 days after the onset of symptoms.

To search for an association between the presence of an obstruction on MRI and the severity of olfactory loss, at inclusion and after 30 days of treatment.

Trial design: Two center, open-label, 2-arm (1:1 ratio) parallel group randomized controlled superiority trial.

Participants: Inclusion criteria

- Patient over 18 years of age;

- Patient with a suspected SARS-CoV-2 infection, whether or not confirmed by PCR, or close contact with a PCRconfirmed case, typical chest CT scan (unsystematic frosted glass patches with predominantly sub-pleural appearance, and at a later stage, alveolar condensation without excavation or nodules or masses) or positive serology ; - Patient with isolated sudden onset hyposmia persisting 30 days after the onset of symptoms of CoV-2 SARS infection;

- Affiliate or beneficiary of a social security scheme;

- Written consent to participate in the study.

Non-inclusion criteria

- Known hypersensitivity to budesonide or any of the excipients;

- Hemostasis disorder or epistaxis;

- Oral-nasal and ophthalmic herpes virus infection;

(Continued on next page)
}

\footnotetext{
* Correspondence: mdaval@for.paris

'Hopital Fondation Adolphe de Rothschild, Paris, France

Full list of author information is available at the end of the article
}

(c) The Author(s). 2020 Open Access This article is licensed under a Creative Commons Attribution 4.0 International License, which permits use, sharing, adaptation, distribution and reproduction in any medium or format, as long as you give appropriate credit to the original author(s) and the source, provide a link to the Creative Commons licence, and indicate if changes were made. The images or other third party material in this article are included in the article's Creative Commons licence, unless indicated otherwise in a credit line to the material. If material is not included in the article's Creative Commons licence and your intended use is not permitted by statutory regulation or exceeds the permitted use, you will need to obtain permission directly from the copyright holder. To view a copy of this licence, visit http://creativecommons.org/licenses/by/4.0/. The Creative Commons Public Domain Dedication waiver (http://creativecommons.org/publicdomain/zero/1.0/) applies to the data made available in this article, unless otherwise stated in a credit line to the data. 
(Continued from previous page)

- Long-term corticosteroid treatment;

- Treatment with potent CYP3A4 inhibitors (e.g., ketoconazole, itraconazole, voriconazole, posaconazole,

clarithromycin, telithromycin, nefazodone and HIV protease inhibitors);

- Severe forms of SARS-CoV-2 with respiratory or other signs;

- Hyposmia persisting for more than 90 days after the onset of symptoms

- Other causes of hyposmia found on interrogation or MRl;

- Patient benefiting from a legal protection measure;

- Pregnant or breastfeeding women.

The participants will be recruited from: Hôpital Fondation Adolphe de Rothschild and Hôpital Lariboisière in Paris, France

Intervention and comparator: Intervention:

Experimental group: Nasal irrigation with budesonide and physiological saline (Budesonide $1 \mathrm{mg} / 2 \mathrm{~mL}$ diluted in $250 \mathrm{~mL}$ of physiological saline 9\% 100 ): 3 syringes of $20 \mathrm{~mL}$ in each nasal cavity, morning and evening, for 30 days, in addition to olfactory rehabilitation twice a day.

Control group: Nasal irrigation with physiological saline $9 \% 00$ only: 3 syringes of 20cc in each nasal cavity, morning and evening, for 30 days, in addition to olfactory rehabilitation twice a day.

Main outcomes: Percentage of patients with an improvement of more than 2 points on the ODORATEST score after 30 days of treatment.

Randomisation: Patients will be randomized (1:1) between the experimental and control groups, using the e-CRF. The randomization list will be stratified by centre.

Blinding (masking): Participants and caregivers are aware of the group assignment. People assessing the outcomes are blinded to the group assignment

Numbers to be randomised (sample size)

120 patients are planned to be randomized into two groups of 60 patients.

Trial Status: MDL_2020_10. Version number 2, May 22, 2020. Recruitment started on May 22, 2020. The trial will finish recruiting by August 2020.

Trial registration: EUDRACT number: 2020-001667-85; date of trial registration: 15 May 2020 Protocol registered on ClinicalTrial.gov, registration number: NCT04361474; date of trial registration: 24 April 2020.

Full protocol: The full protocol is attached as an additional file, accessible from the Trials website (Additional file 1). In the interest in expediting dissemination of this material, the familiar formatting has been eliminated; this Letter serves as a summary of the key elements of the full protocol.

Keywords: COVID-19, Randomised controlled trial, rotocol, hyposmia, dysgeusia, nasal irrigation, corticosteroid, budesonide, MRI

\section{Supplementary information}

Supplementary information accompanies this paper at https://doi.org/10. 1186/s13063-020-04585-8.

Additional file 1. Full Study Protocol.

\section{Acknowledgements}

We thank Corinne Eloi for useful discussion and Chloé Le Cossec for support.

\section{Authors' contributions}

$M D, C h H, A C$ and $D S$ conceived of the study. MD, ChH, AC, DS, BV, initiated the study design and $C P$ helped with implementation. $C P$ and $C J$ provided statistical expertise in clinical trial design. GP and ME provided imaging expertise.DS and DS provided the viral expertise. $\mathrm{MD}, \mathrm{ChH}, \mathrm{JH}, \mathrm{CaH}$ and $W E B$ carried out the olfactory tests and refined the questionnaires. $D A$ and $P H$ supervised the project. All authors contributed to refinement of the study protocol and approved the final manuscript.

\section{Funding}

The study is funded by the French Department of Health (Innovarc). Funding for this trial covers the run-in costs (clinical and paraclinicals examinations, treatments, data exploitation.

Availability of data and materials

Each investigator will have access to the final trial dataset. Project data sets are housed on the Project Accept Web site (Clinfile), and all data sets are password protected. Project Principal Investigators have direct access to their own site's data sets. To ensure confidentiality, data dispersed to project team members will be blinded of any identifying participant information data will be available from the author on reasonable request (mdaval@for.paris).

Ethics approval and consent to participate

ANSM and CPP approved the study.

MEDAECNAT-2020-04-00075 approval was granted on May 14, 2020

CPP SUD EST II (2020-39) approval was granted on April 24, 2020. An amendment was accepted on June 3, 2020 to allow the inclusion of patients with persistent hyposmia up to 90 days after the onset of signs of COVID. 
We declare that we certify that this trial has received ethical approval from the appropriate ethical committee described above. Each participant has to read an information note and signed a consent form for participation.

\section{Consent for publication}

Not applicable

\section{Competing interests}

The authors declare that they have no competing interests.

\section{Author details}

${ }^{1}$ Hopital Fondation Adolphe de Rothschild, Paris, France. ${ }^{2}$ Hopital Lariboisiere, Paris, France. ${ }^{3}$ Hotel Dieu Hospital, Paris, France.

Received: 1 July 2020 Accepted: 4 July 2020

Published online: 20 July 2020

\section{Publisher's Note}

Springer Nature remains neutral with regard to jurisdictional claims in published maps and institutional affiliations.

\section{Ready to submit your research? Choose BMC and benefit from:}

- fast, convenient online submission

- thorough peer review by experienced researchers in your field

- rapid publication on acceptance

- support for research data, including large and complex data types

- gold Open Access which fosters wider collaboration and increased citations

- maximum visibility for your research: over $100 \mathrm{M}$ website views per year

At $\mathrm{BMC}$, research is always in progress. 